\title{
Squamous Cell Carcinoma of the Conjunctiva
}

\author{
Wilson IB Onuigbo*
}

Department of Pathology, Medical Foundation \& Clinic, Nigeria

*Corresponding author: Wilson IB Onuigbo, Department of Pathology, Medical Foundation \& Clinic, Enugu 400001.

Submission: 跲 April 07, 2018; Published: 眥 May 29, 2018

\begin{abstract}
From single to numerous cases of squamous cell carcinoma (SCC) have been reported from different countries. One report from Kenya generalized that the African picture is different. Therefore, the Nigerian pattern is presented here. It does not support the above generalization.

Keywords: Conjunctiva; Squamous cell carcinoma; World pattern; African pattern; Nigeria
\end{abstract}

\section{Introduction}

Squamous cell carcinoma (SCC) of the conjunctiva is an important disease with world-wide distribution. The present search revealed cases in alphabetical order in Australia [1], Chile [2], Germany [3], India [4,5], Japan [6], Kenya [7], Mexico [8], and USA [9]. Collectively, they provide data for comparison with the local data.

\section{Investigation}

A Birmingham (UK) group hypothesized that the establishment of a histopathology data pool enhances epidemiological analysis [10]. Now, for the Igbo ethnic group in Nigeria [11], such a pool became available for research since 1970 when the author became the pioneer pathologist. Moreover, since I kept a personal copy of all the materials, their analysis became easy. Indeed, the tabular form made matters even easier.

\section{Result}

Result is discussed in Table 1.

\section{Discussion}

One salient point came from Kenya authors [7]. In their view, concerning ocular surface squamous neoplasia (OSSN), "In equatorial Africa, OSSN affects younger adults and proportionally more women than in other parts of the world." As Table 1 shows, this is not true of Nigeria. In fact, in Mexico [8], the mean age of the patients was (60.4) range 12 to 99 years, $55 \%$ being male. In this context, the above Nigerian trend was from 29 years to 100 years (mean 46 years), 61\% being male. The question of association with HIV-infection was raised in Kenya [12]. None of the present cohort was reported to be involved. Similarly, there was the report of orbital exenteration in Australia [1] Chile [2], and Germany [3]. None of the present cases was treated like that. Apparently, what transpired necessarily was "wide local excision" as in USA [9].

Table 1: Epidemiological data on squamous cell carcinoma of the conjunctiva.

\begin{tabular}{|c|c|c|c|}
\hline Age & Male & Female & Total \\
\hline$<30$ & 2 & 1 & 3 \\
\hline $31-40$ & 7 & 2 & 7 \\
\hline $41-50$ & 6 & 1 & 5 \\
\hline $51-60$ & 2 & 1 & 3 \\
\hline $61-70$ & 2 & 1 & 3 \\
\hline $71-80$ & 2 & 1 & 1 \\
\hline $81-90$ & - & - & 1 \\
\hline $91-100$ & 22 & 10 & 32 \\
\hline Total & & & \\
\hline
\end{tabular}




\section{Conclusion}

In conclusion, Japanese authors treated a 94-year-old woman [6]. Their report ended thus: "Although it is extremely rare that SCC of the conjunctiva is the initial finding in a patient with systemic cancer, careful systemic examination to find other cancers should be made." Indeed, conjunctival SCC itself is ripe far worldwide research.

\section{References}

1. McKelvie PA, Daniell M, McNab A, Loughnan M, Santamaria JD (2002) Squamous cell carcinoma of the conjunctiva: A series of 26 cases. Br J Ophthalmol 86(2): 168-173.

2. Espildora IG, Jans J, Guajardo MP (2016) Squamous cell carcinoma of the conjunctiva with extraocular involvement: Case report and literature review. Medwave 16(4): e6453.

3. Miller CV, Wolf A, Klingenstein A, C Decker, A Garipet, et al. (2014) Clinical outcome of advanced squamous cell carcinoma of the conjunctiva. Eye 28(8): 962-967.

4. Midena E, Angeli CD, Valenti M, de Belvis V, Boccato P (2000) Treatment of conjunctival squamous cell carcinoma with topical 5-fluorouracil. Br J Ophthalmol 84(3): 286-272.
5. Saini N, Hasija S, Gill MK, Shivani Kalhan, Satya Dutta (2017) Conunctival squamous cell carcinoma, a rare entity: Case report of 2 cases. Oncol Cancer Case Rep 3: 132 .

6. Mitamura H, Oshitari T, Kimoto R, Yotsukura J, Asanagi K, et al. A case of squamous cell carcinoma of conjunctiva as initial sign of systemic cancers. Case Rep Ophthalmol Med 2011(2011): 972318, p. 3.

7. Gichuhi S, Sagoo MS (2016) Squamous cell carcinoma of the conjunctiva. Comm Eye Helth 9(95): 52-53.

8. Cervantes G, Rodriguez AA, Leal AG (2002) Squamous cell carcinoma of the conjunctiva: Clinicopathological features in 287 cases. Canad J Ophthalmol 37(1): 14-20.

9. Choi CJ, Stagner AM, Jakobiec FA, Nahyoung Grace Lee (2016) Nonlimbal squamous cell carcinoma of the conjunctiva. Ophthalmology 123(2): 254.

10. Macartney JC, Rollaston TP, Codling BW (1980) Use of a histopathology data pool for epidemiological analysis. J Clin Pathol 33(4): 351-353.

11. Basden GT (1966) Niger Ibos. Cass, Lond.

12. Gichuhi S, Irlam JH (2013) Interventions for squamous cell carcinoma of the conjunctiva in HIV-infected individuals. Cochrane Database Syst Rev 28(2): CD005643.
Creative Commons Attribution 4.0 International License

For possible submissions Click Here

\section{Submit Article}

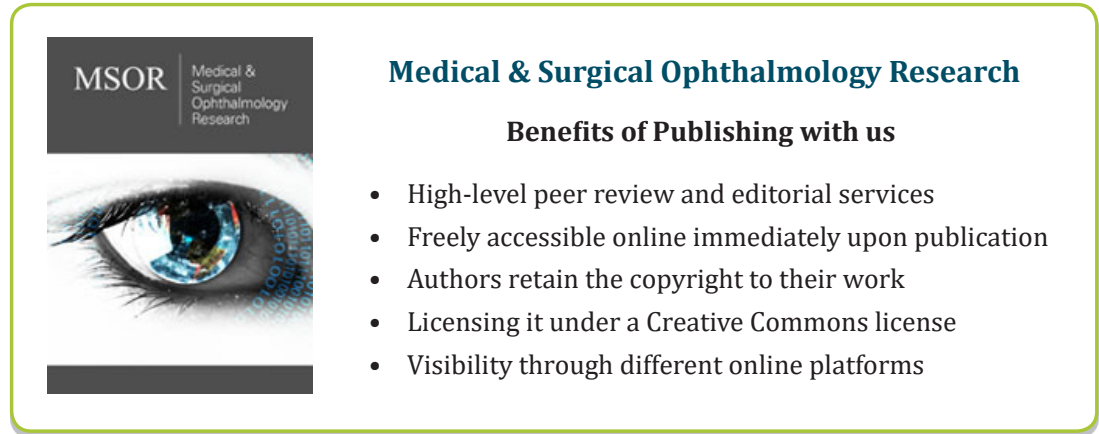

